technokratické rozhodovatele. Předposlední kapitola zmiňuje dlouhodobé fiskální výzvy. Jak dává tušit název, jde zejména o dopady výdajů dané stárnutím populace $\mathrm{v}$ drtivé většině zemí Evropské unie. Výdaje na penze a zdravotní péči jsou analyzovány jak v současnosti, tak s výhledem do roku 2050 s uvedením možných reformních kroků v obou oblastech. Závěrečná kapitola shrnuje výsledky podrobných analytických rozborů ve všech kapitolách a předkládá čtenáři závěry shrnuté do 10 bodů, které si zasluhují vyjmenování: 1) Žádná země nemůže ignorovat vážnost fiskálních problémů, přinejmenším ne navždy; 2) V dobrých časech je nutno se připravovat na zlé časy; 3) V určitých př́ipadech může být fiskální politika efektivním nástrojem stabilizace; 4) Fiskální multiplikátory mohou být relativně velké při značné mezeře výstupu a omezených možnostech měnové politiky; 5) Ekonomický růst může značně usnadnit fiskální udržitelnost; 6) Důvěryhodnost je důležitá a je důvodem, proč některé země mohou mít vyšší dluhový poměr nežli jiné země; 7) Pro úspěch fiskální konsolidace jsou podstatné politicko-ekonomické úvahy a vhodný mix zvyšování př́ijmů a snižování výdajů; 8) Měnovou unii nelze udržet bez adekvátní fiskální integrace; 9) Ve většině zemí je nutné posilovat fiskální instituce; 10) Zvláštní pozornost se musí věnovat rizikům finančního sektoru vzhledem $\mathrm{k}$ devastujícím dopadům finanční krize na fiskální situaci a na celou ekonomiku.

Toto krédo pracovníků Mezinárodního měnového fondu vyplývá z velmi detailní analýzy 45 autorů rozebírající různé aspekty fiskální politiky v celkovém rámci hospodářsko-politických opatření jak ve vyspělých, tak v rozvíjejících se ekonomikách, což je dáno pozicí zmíněné instituce. Vedle velmi podrobné empirické analýzy, včetně uvádění výsledků ekonometrických analýz, kniha shrnuje i teoretické poznatky. Každá kapitola uvádí, kromě případných př́íloh, rozsáhlý přehled literatury týkající se problémů v kapitole rozebíraných. Celkově jde o nepostradatelný zdroj poznání pro ekonomy zajímající se o současný stav výzkumu v dané oblasti. Opominout nelze ani doporučení významných ekonomů (A. Auerbach, Kalifornská univerzita, Berkeley; J. Poterba, President, Národní úřad pro ekonomický výzkum; T. Sargent, New York University, držitel Nobelovy ceny za ekonomii za rok 2011) otištěné na zadní stránce knihy.

\title{
Anotace
}

\section{Adrián Podskían a kol.: Adaptivní organizace. Inspirace od Bati po Jobse na cestě $k$ firemní dlouhověkosti}

\author{
10.18267/j.polek.1044
}

Kdo by neznal verše Jana Nerudy: „Kdo chvíli stál, už stojí opodál - den žádný dvakrát se již nenarodí, čin dvakrát neuzraje.“ Až pozoruhodně přesně básník už před mnohými desetiletími formuloval to, co je v dnešním světě managementu označováno za princip agility: všechny organizace mají v zájmu svého přežití co nejrychleji, ohleduplně a efektivně reagovat na všechny vnější i vnitřní podněty a změny. Mnoho manažerů českých i zahraničních firem pak hledá odpověd' na základní otázku: Co tedy dělat pro to, abychom se za pár let nemuseli ptát, kde jsme to pokazili? Autorský kolektiv pod vedením Adriána Podskĺana ve své nejnovější publikaci podává 
srozumitelný, byt' ne naprosto novátorský návod, podepřený mnoha zkušenostmi a dobrou praxí. Za adaptivní autoři považují takovou organizaci, která má pracovníky ochotné realizovat změny, dokáže optimalizovat spotřebu svých zdrojů a pružně se přizpůsobit změnám požadavků nejenom zákazníků, ale i jiných zájmových skupin. Onen návod na dosažení takového stavu organizací je obsažen na 174 stranách poutavě zpracovaného textu, z pohledu čtenářo̊ dobře strukturovaného do sedmi základních kapitol.

Hned první kapitola zaujme nejenom vymezením pojmu ,adaptivní organizace“, ale především analýzou dvanácti nejzávažnějších bariér jejího budování - od klasické organizační struktury až po nedostatek účelu. Společným jmenovatelem je pak zejména nedostatek vůle, trpělivosti a znalostí u vedení jednotlivých organizací. Ve druhé kapitole najdeme čtyři proklamativní doporučení jak najít správnou cestu $\mathrm{k}$ dosažení pružnosti a adaptivnosti organizací. I v dalších kapitolách čtenár najde mnoho dalších poznatků a doporučení, shrnutých do takových názvů dílčích částí knihy, jako např. Bud'te inovativní, agilní a autonomni, Konejte společensky odpovédně, Fungujte jako živý organismus apod. Ti, kteří čtou manažerskou literaturu pravidelně, se už určitě s podobnými výzvami setkali a mohou jim tak připadat už „okoukané“. To je však jen první dojem, protože v každé z těchto částí autoři své názory a podněty precizují. Nepodávají podrobné návody (což ani není možné vzhledem $\mathrm{k}$ tomu, že každá firma je jedinečným organismem), ale plně vystihují první polovinu pořekadla „moudrému napověz...". Chci tím pouze naznačit, že autoři plně spoléhají na to, že se najde snad i rozsáhlá skupina čtenářru, kteří se nechají inspirovat $\mathrm{k}$ tvořivé adaptaci doporučení, jež jsou v knize nenásilně a přece důrazně podávána! Nicméně je zřejmé, že realizace tak zásadní proměny $\mathrm{z}$,klasické“ na adaptivní organizace bude vždy během na dlouhou trat'. Je proto i zcela pochopitelné, že poslední kapitola, orientovaná na popis prínosů adaptivní organizace, postrádá širší spektrum přesvědčivých důkazů o efektech jak ekonomických, tak i společenských, které tvorba adaptivní organizace přináśí.

Není vůbec na škodu, že si autoři v textu vypomáhají mnoha citáty takových osobností, jako jsou T. Bat’a, M. Zelený, T. Hardford a další. Vůbec nejde o jakési berličky, naopak činí text ještě přitažlivějším, stejně jako některé příklady dobré praxe, jež se k doporučením autorů at' už přímo, či nepřímo váží.

Publikace je psána čtivým a srozumitelným způsobem, aniž by se to negativně odrazilo na její odborné úrovni. I když bychom mohli každé z dílčích doporučení autorů považovat za známé a už i mnohokrát $\mathrm{v}$ literatuře popsané, kniha je cenná tím, že z těchto jednotlivých doporučení udělala kompaktní celek. Číst by ji měli především ti manažeři, kteří se bezskrupulózně snaží pouze o maximalizaci krátkodobých zisků a využívají některé konjunkturální trendy, v ekonomice se z času na čas objevující. Nejsem si jist, zda to bylo prvotním smyslem napsání této publikace, ale osobně velmi naléhavě z textu všech kapitol cítím výzvu ke společensky odpovědnému chování všech typů organizací, aby i děti našich dětí mohly svůj život prožít alespoň $\mathrm{v}$ té kvalitě, jaká byla poskytnuta $\mathrm{k}$ našim vlastním životům! Pozoruhodný a dosud výjimečný je i další aspekt: vydání knihy (a zejména její koupě) pomáhá absolventům Jedličkova ústavu $\mathrm{v}$ jejich pracovním zařazení. Už i proto, a nejen $\mathrm{z}$ tohoto důvodu, plně doporučuji tuto publikaci $\mathrm{k}$ podrobnému studiu.

\section{Vydalo: Nakladatelství Management Press, Praha, 2015. $174 \mathrm{~s}$. \\ ISBN 978-80-7261-336-6.}

Jaroslav Nenadál 